\title{
Tuhar pulse flowers corroding by corrosive pollutants
}

\author{
Rajesh Kumar Singh \\ Department of Chemistry, Jagdam College, J P University, Chapra, India. \\ Accepted 4 June, 2013
}

\begin{abstract}
Tuhar (Arhar) pulse is a very important crop of Indian farmers. It is one of the most proteinous foods of the public. It is a common food for Indian people. It is cultivated mostly in Madhya Pradesh, Rajasthan, Gujarat, Maharastra, Uttar Pradesh, Bihar and West Bengal. Recently, in these states, industrialization and infrastructure development works are going very fast causing huge amounts of pollutants and particulate entering into the atmosphere. Pollutants are oxide of carbon, oxide of nitrogen, oxide of sulphur, oxide of chlorine, chloride ions, ammonia, organic acids and aldehydes; whereas particulates are dust, smoke, mist and fog. Particulates are deposited on the surface of arhar pulse flower. Some of these particulates are hydroscopic in nature. They absorb pollutants and form acids. These acids in turn develop micro electrochemical cell with flower of Tuhar pulse which destroy flowering of arhar pulse. Other factors are acid rain, global warming and depletion of ozone layer affecting the production of arhar pulse.
\end{abstract}

Key words: Tuhar (Arhar) pulse flowers, pollutants, particulates, micro electrochemical cell, acid rain, global warming, ozone depletion.

\section{INTRODUCTION}

Arhar pulse is cultivated in the Basin of Ganga River, Yamuna, Gomati, Narmada, Godawari, Mahananda and other areas. These areas are flooded with industries (Pitts, 1986) like chemical, coal, fertilizer, petroleum refinery, food processing, transport industry, coal power, hydropower, drug industry, pulp and paper industry, paint and dyes, sugar industry, wine industry, water bottling plant, juice factory, milk processing etc. These industries release huge amount of pollutants (Masters, 1994) like inorganic, organic and particulates material (Williamson, 1973). They pollute air (Crwford, 1976) and that polluted air produces several problems (Murray et al., 1975) for living and nonliving things. Inorganic pollutants are oxide of carbon $\left(\mathrm{CO}, \mathrm{CO}_{2}\right)$, oxide of nitrogen $\left(\mathrm{NO}, \mathrm{N}_{2} \mathrm{O}, \mathrm{NO}_{2}\right)$, oxide of sulphur $\left(\mathrm{SO}_{2}, \mathrm{SO}_{3}\right)$, oxide of chlorine, chlorine ion, ammonia and oxide of metal. Organic pollutants are organic acid, aldeyhde, ketone, amine etc. Particulates (Wayne, 1991) are dust, smoke, mist, pollen, bacteria and fog.

Arhar pulse flowering period starts from December to
February. Particulates are scattered into the atmosphere which are deposited on the surface of arhar pulse. Some of these particulates are hydroscopic in nature. They absorb moisture (Sugden, 1978) from the atmosphere. The moist particulates absorb oxide of carbon, oxide of nitrogen, oxide of sulpher, oxide of chlorine and chlorine ion to form carbonic acid, nitric acid, sulphuric acid, hypochlorous acid and hydrochloric acid. These acids are highly corrosive in nature. They create hostile environment for arhar pulse flowers. The corrosive acid produces micro electrochemical cell with arhar pulse flowers; thus, electrochemical reaction occurs on the surface of wheat flowers. In this way flowers of arhar pulse get destroyed and conversion of flowers into arhar pulse is decreased.

\section{METHODOLOGY}

For this work, certain arhar pulse growing areas were selected like Chindwara in Madhya Pradesh, Bharatpur in Rajasthan, Lucknow in Uttar Pradesh and Patna in Bihar. The study of the characteristic 
Table 1. $\mathrm{pH}$ values of corrosive pollutants in different cities.

\begin{tabular}{lcccc}
\hline City & Chindavra & Lucknow & Bharatpur & Patna \\
\hline $\mathrm{pH}$ & 5.6 & 5.8 & 6.3 & 6.5 \\
\hline
\end{tabular}

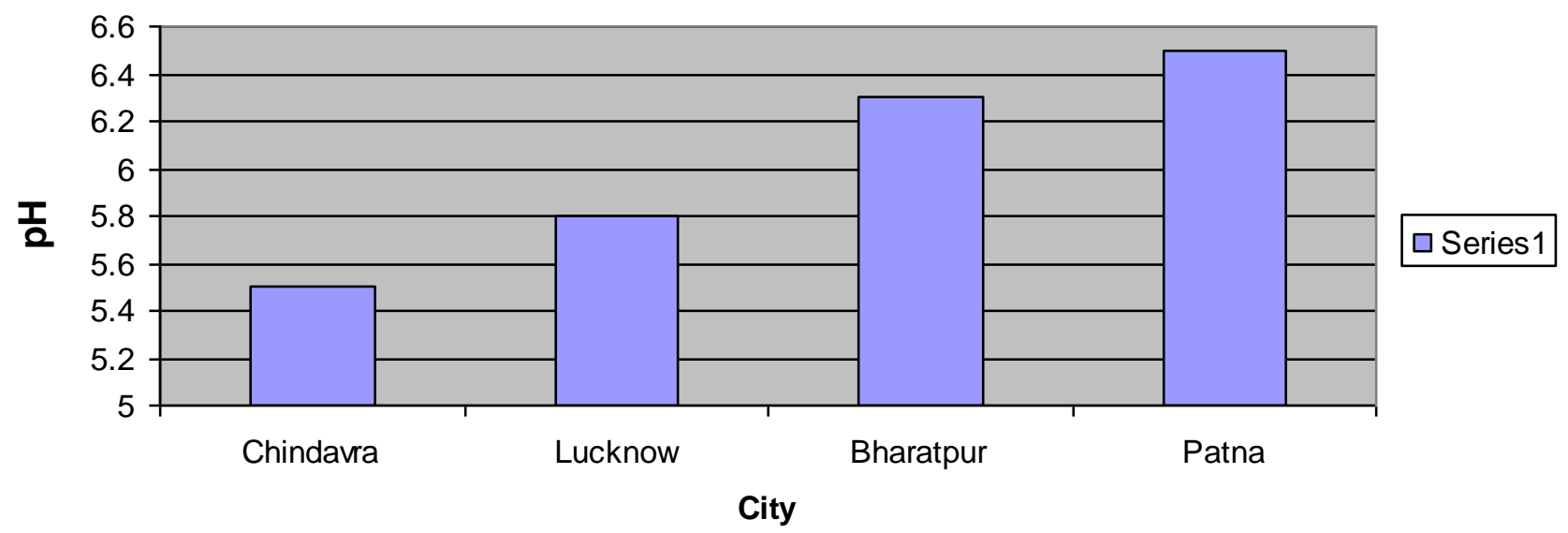

Figure 1. Plot between City and $\mathrm{pH}$ values of acids in different cities.

behaviors of inorganic, organic and particulates pollutants and their effect on arhar pulse flowers were done in detail. Monitoring works started during the period of December to February. Corrosive gases and their acidic character were determined with the help of Pen type $\mathrm{pH}$ meter.

\section{RESULTS AND DISCUSSION}

Arhar pulse is one of the main foods of Indian people. Our country is highly populated. Our public have so many basic needs like food, clothe, house, education, hospital, electricity, transport, road, industry and telecommunication. For the completion of these basic needs, we do not utilize our natural resources in proper manner. Man creates its own environments. The infrastructure development works are going very fast in several sectors like industry, agriculture, power generation, construction etc. These sectors have major role in pollution of environment. The main features of Tuhar depend upon temperature, humidity and nature of surrounding environment during its flowering period. The concentration of corrosive gases, particulate materials and humidity are high so they form $\mathrm{H}_{2} \mathrm{CO}_{3}, \mathrm{HNO}_{3}, \mathrm{H}_{2} \mathrm{SO}_{4}, \mathrm{HClO}$ and $\mathrm{HCl}$. These acids produce $\mathrm{H}^{+}$ion that ion starts electrochemical reaction with Tuhar flowers. Due to this reaction, flowers connectivity becomes weaker and finally they are detached from the main branch of Tuhar plant.

During the formation of acids, exothermic reaction occurs and heat is evolved which increases the temperature of the surrounding of Tuhar flowers, causing the separation of Tuhar flowers from its main branch. The chemical reactions among them are written as:

$\begin{array}{lllll}\mathrm{CO}_{2}+ & \mathrm{H}_{2} \mathrm{O} & \rightarrow & \mathrm{H}_{2} \mathrm{CO}_{3} \\ \mathrm{NO}+ & \mathrm{O}_{2} & \rightarrow & \mathrm{NO}_{2} \\ \mathrm{NO}_{2}+ & \mathrm{H}_{2} \mathrm{O} & \rightarrow & \mathrm{HNO}_{3} \\ \mathrm{SO}_{2}+ & \mathrm{O}_{2} & \rightarrow & \mathrm{SO}_{3} \\ \mathrm{SO}_{3}+ & \mathrm{H}_{2} \mathrm{O} & \rightarrow & \mathrm{H}_{2} \mathrm{SO}_{4} \\ \mathrm{Cl}^{-}+ & \mathrm{H}_{2} \mathrm{O} & \rightarrow & \mathrm{HCl}+\mathrm{ClO}^{-}\end{array}$

The aforementioned acids are dissociated and released $\mathrm{H}^{+}$ion that ions in the presence of electrolytes develop an electrochemical cell causing oxidation and reduction reactions to start on the surface of arhar pulse flowers. The electrochemical reaction is expressed as:

Half oxidation reaction

$\left(\mathrm{CH}_{2} \mathrm{O}\right) \mathrm{n} \rightarrow \mathrm{nCO}_{2}+2 \mathrm{H}^{+}+2 \mathrm{e}$

Carbohydrate

Half reduction reaction

$2 \mathrm{H}^{+}+2 \mathrm{e} \rightarrow \mathrm{H}_{2}$

This chemical reaction indicates that corrosive pollutants are corroding the arhar pulse flowers. The PH values of aforementioned cities are recorded in Table 1 and bar graph plots between the $\mathrm{pH}$ values of corrosive pollutants and its concentrations in different cities.

The results of Table 1 and Figure 1 show that the concentration of $\mathrm{H}^{+}$ion in Chindwara city is higher than that of Lucknow. Likewise the concentration of $\mathrm{H}^{+}$ion in Bharatpur is greater than Patna and arhar pulse crops of 
these areas are badly affected by pollutants. The concentration of carbon dioxide and methane gases increases in atmosphere due to deforestation, industrialization and human waste decomposition. These gases produce global warming effect; thus, temperature of atmosphere is increased which exhibits a bad affect on the Arhar pulse flowers.

In lower level of atmosphere, ozone is formed and that ozone also disturbs arhar pulse flowers.

$\begin{array}{lllll}\mathrm{O}_{2} & + & \mathrm{UV} & \rightarrow & \mathrm{O}_{2} \\ \mathrm{O}_{2} & + & \mathrm{O} & \rightarrow & \mathrm{O}_{3}\end{array}$

\section{Conclusion}

Pollutants are very harmful for arhar pulse flowers. They decrease its production. If its evolvement is not controlled at proper times, our country will become major loser of this pulse. It is moral responsibility of the industrialists, scientists, intellectuals, social workers to provide good technology and public awareness against pollution.

\section{REFERENCES}

Crwford M (1976). Air Pollution Control Theory. Mc Grow Hill, New York. pp. 234-236.

Masters GM (1994). Introduction to Environmental Engineering and Science. Prentice Hall, New Delhi. p. 75-80.

Murray J, Me Ewan, Leon F. Philips (1975). Chemistry of Atmosphere. Halsted (Wiley), New York. pp. 23-26.

Pitts BJ (1986). Atmosphere Chemistry, Academic Press, Wiley, New York. pp. 1-5.

Sugden TM (Ed) (1978).Pathways of Pollutants in the Atmosphere. The Royal Society, London. p. 123-125.

Wayne RP (1991).The Chemistry of the Atmosphere. Oxford Univ. Press, New York. pp. 76-80

Williamson J (1973). Fundamentals of Air Pollution. Addison - Wesley, Reading, Mass, USA. pp. 100-105. 